\title{
Methane Formation by the Reaction of Coalbed Carbon with Water
}

\author{
V. E. Vigdergauz \\ Russian Academy of Sciences, Moscow, Russia \\ E-mail:vigderg@mail.ru \\ Received February 14, 2011; revised March 2, 2011; accepted March 21, 2011
}

\begin{abstract}
There is proposed a mechanism of methane and carbon dioxide formation by the direct reaction of carbon with water during catastrophic events in the mining of coal deposits. Thermodynamics of the reaction is discussed.
\end{abstract}

Keywords: Methane Formation, Coal Mining, Water, Carbon Dioxide, Reaction Thermodynamics

\section{Introduction}

Mechanism of methane formation is a key question in an understanding of the reasons of its "huge reserves" and the role in "unpredictable catastrophes" [1]. There are three main reasons for our interest to the problem [2]:

Association of methane with coal has always presented a safety problem in mines due to the potential for explosions. Mixtures of methane and air, with the methane content between 5 and 14 percent by volume, are explosive. Explosions of such mixtures have been frequent in coal mines and collieries and have been the cause of many mine disasters;

Interest in the recovery of methane from coalbeds has increased rapidly over recent years, because of its potential as an energy resource and to alleviate pollution and safety problems;

Methane contributes to the adverse environmental impacts of global warming, tropospheric ozone formation (smog), and potentially stratospheric ozone destruction.

Its evolution during exploitation of coal deposits is a source of numerous speculations but not really understandable till now. Traditionally three mechanisms for methane formation are considered [2]: (1) nonbiogenic formation, (2) formation by anaerobic bacteria during plant material deposition and the early stages of diagenesis, and (3) formation from pyrolysis of coal material during coal maturation.

All three mechanisms do not explain a fast and unpredictable evolution of huge amounts of the gas in the processes of an exploration of coal deposits. Controversies are connected with the attempts to consider desorption of methane from the coal despite of its formation.
It is well known that in the case of catastrophic events during exploitation of coal deposits there are observed sudden waste of methane and carbon dioxide. One of the biggest sudden wastes of gases from the coal occurred in 1921 in France in the Gard district on the mine Nord'Alle [1]. Of the deposit sudden burst such amount of carbon dioxide that it flood the mine, poured on the surface and submerge small town that was situated in the lowlands.

During the catastrophic events the volume of the emitted gases in some cases could reach hundreds cubic meters per tone of the thrown coal. The process that leads to such catastrophic events is not quite understandable till now. We know two products of the reaction - methane and carbon dioxide, and one of the reactants - coalbed carbon. Coal substance contents some amounts of hydrogen but these quantities are too small for the balance. The main question is the source of the huge amounts of hydrogen and a probable answer that it is water.

From the practice of coal mining it is known the cooling of the coal bed before the sudden waste [1] that is shows the endothermic character of the processes which are observed before the sudden waste event.

The goal of the presented paper is to check up a thermodynamic probability of methane nonbiogenic formation directly from coalbed carbon and water in the conditions of exploitation of coal deposits.

\section{Reaction Termodynamics}

According to Gibbs equation Gibbs free energy change under standard conditions is equal to the total energy changes for the system minus energy lost in the disordering of the system: 


$$
\Delta \mathrm{G}=\Delta \mathrm{H}-\mathrm{T} \Delta \mathrm{S}
$$

There are two common methods of calculating of $\Delta \mathrm{G}$ for chemical reactions - determine $\Delta \mathrm{H}_{\mathrm{rxn}}$ and $\Delta \mathrm{S}_{\mathrm{rxn}}$ and use Gibbs equation or use tabulated values of free energies of formation, $\Delta \mathrm{G}_{\mathrm{f}}$.

The table summarizes molar thermodynamic characteristics of substances which will be used for an analysis.

Standard molar thermodynamic characteristics of substances [3].

\begin{tabular}{lccc}
\hline \multicolumn{1}{c}{ Substances } & $\Delta \mathrm{H}_{\mathrm{f} 298}, \mathrm{~kJ} / \mathrm{mol}$ & $\Delta$ & $\Delta$ \\
$\mathrm{C}(\mathrm{s})$, graphite & 0 & 32.1 & -9.566 \\
$\mathrm{~S}_{2} \mathrm{O}(\mathrm{l})$ & -285.83 & 69.95 & -306.675 \\
$\mathrm{O}_{2}(\mathrm{~g})$ & 0 & 161.1 & -48.008 \\
$\mathrm{CH}_{4}(\mathrm{~g})$ & -74.87 & 188 & -130.894 \\
$\mathrm{CO}(\mathrm{g})$ & -110.53 & 197.66 & -169.433 \\
$\mathrm{CO}_{2}(\mathrm{~g})$ & -393.52 & 213.79 & -457.229 \\
\hline
\end{tabular}

Proposed model describes a formation of methane from a coal by the direct interaction of carbon with water.
Direct reduction of hydrogen from its oxide by coal in the form of graphite carbon could be represented by the equation:

$$
\begin{gathered}
2 \mathrm{C}+2 \mathrm{H}_{2} \mathrm{O}=\mathrm{CH}_{4}+\mathrm{CO}_{2} \\
\Delta \mathrm{G}_{\mathrm{rxn}}=44.36 \mathrm{~kJ} / \mathrm{mol} \text { of methane }
\end{gathered}
$$

The above reaction 2 is an endothermic one, but the products entropy increases and the reaction could be product-favored. Changes of the reaction 2 entropy $\Delta S_{\mathrm{rxn}}$ $=197.69 \mathrm{~J} / \mathrm{mol} \mathrm{K}$ is positive and this reaction could be an "entropy driven".

Necessary energy could be produced by parallel exothermic processes of partial or total oxidation of methane, such as:

$$
\begin{gathered}
\mathrm{CH}_{4}+2 \mathrm{O}_{2}=\mathrm{CO}_{2}+2 \mathrm{H}_{2} \mathrm{O} \\
\Delta \mathrm{G}_{\mathrm{rxn}}=-843.67 \mathrm{~kJ} / \mathrm{mol} \text { of methane }
\end{gathered}
$$

Summary processes of the generation of coalbed methane and its explosive oxidation are highly exothermic. Scheme illustrates energy change during the process of formation and subsequent oxidation of coal methane:

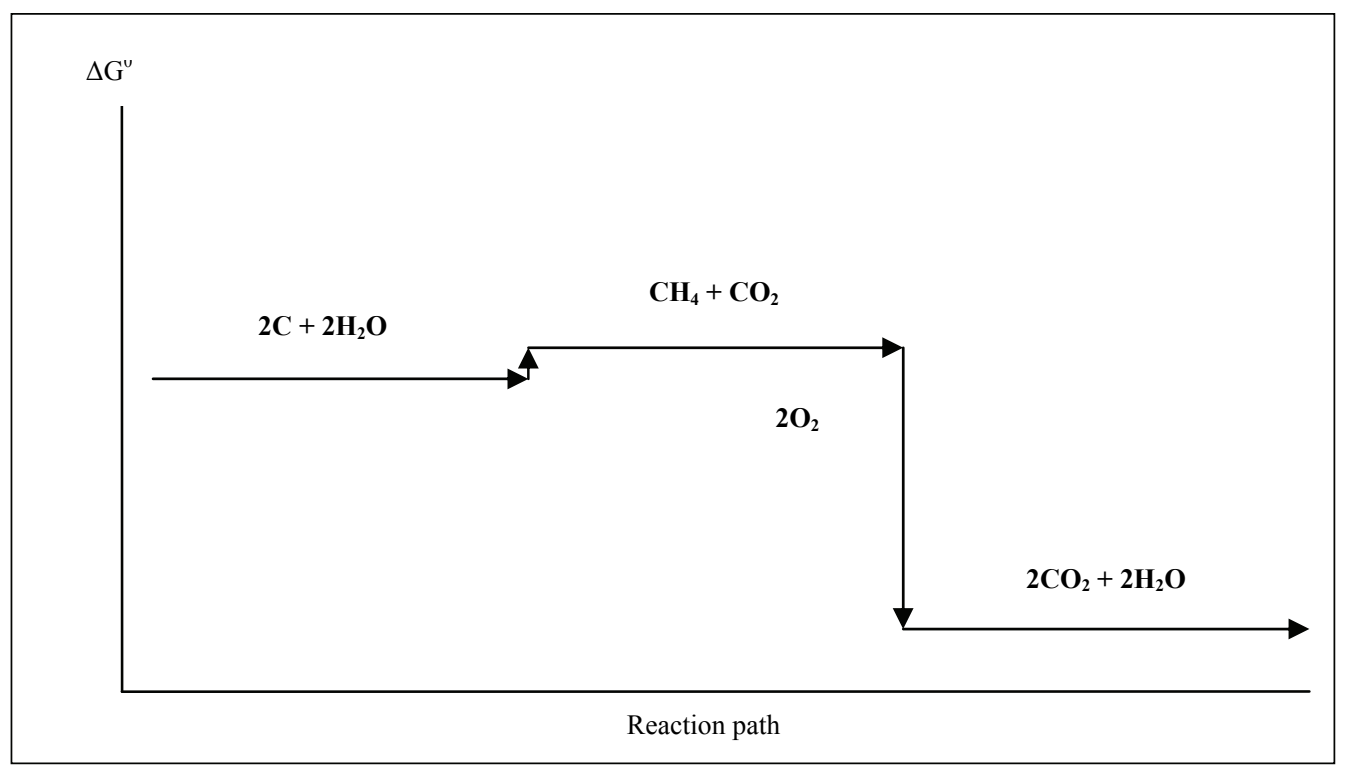

Energy change during the process of formation and subsequent oxidation of coal methane.

Summary energetic effect of carbon oxidation through the pass with methane formation is near $400 \mathrm{~kJ} / \mathrm{mol}$ of carbon.

Reaction energy is undependable from its path and direct oxidation of carbon by oxygen on the reaction:

$$
\begin{gathered}
\mathrm{C}+\mathrm{O}_{2}=\mathrm{CO}_{2} \\
\Delta \mathrm{G}_{\mathrm{rxn}}=-400 \mathrm{~kJ} / \mathrm{mol}
\end{gathered}
$$

gives the same energy and the differences are only in the reaction path and in the values of activation energies.

\section{Field Observations}

The proposed path of methane formation on the reaction of water with coal carbon is indirectly confirmed by the results of environment chemical analysis. By an extensive study of the hydrologic situation in the Fruitland Formation it was shown that the continuity of water coverage of the formation is a crucial question for the formation of methane from coal beds [4]. Chemical analysis of gas and water phases in the areas of Coal-bed Meth- 
ane (CBM) formation also confirms the proposed mechanism [5]. It was observed, that generally, dissolved anions in water co-produced with $\mathrm{CBM}$ contain mainly bicarbonate $\left(\mathrm{HCO}_{3}{ }^{-}\right)$and chloride $\left(\mathrm{Cl}^{-}\right)$. The bicarbonate quantity decreased because this component limits the amount of calcium ( $\mathrm{Ca}$ ) and magnesium $(\mathrm{Mg})$ through the precipitation of carbonate minerals. The composition is controlled in great part by the association of the waters with a gas phase containing varying amounts of carbon dioxide $\left(\mathrm{CO}_{2}\right)$ and methane. Indirect evidence about reductive conditions during CBM formation gives an observation that " $\mathrm{CBM}$ waters are relatively low in sulfate $\left(\mathrm{SO}_{4}\right)$ because the chemical conditions in coal beds favor the conversion of $\mathrm{SO}_{4}$ to sulfide".

Shvartsev et al. [6] have recently shown for the Erunakovo region of the Kuznetsk origin (Russia) that during the coal methane formation a high mineralization of water and the higher contents of $\mathrm{HCO}_{3}^{-}$is mainly observed due to $\mathrm{CO}_{2}$ formation, which is not the product of mantle genesis but is the product of coal metamorphism.

It is mentioned that coal rank increases with burial depth and CBM content increases with increasing rank, so that with greater seam depths, gas contents are expected to increase [7].

In conditions of high pressure and heating (for events of methane blast, for example) the reduction of hydrogen from its oxide could possess as chain-type reactions on the free radical-mechanism:

$$
\begin{aligned}
& \mathrm{C}+\mathrm{H}_{2} \mathrm{O}=\mathrm{CH}^{\cdot}+\mathrm{OH}^{\cdot} \ldots \mathrm{CH}^{\cdot}+\mathrm{H}_{2} \mathrm{O}=\mathrm{CH}_{2}{ }^{\cdot}+\mathrm{OH}^{\cdot} \ldots \\
& \mathrm{CH}_{2}{ }^{\cdot}+\mathrm{H}_{2} \mathrm{O}=\mathrm{CH}_{3}{ }^{\cdot}+\mathrm{OH}^{\cdot} \ldots \mathrm{CH}_{3}{ }^{\circ}+\mathrm{H}_{2} \mathrm{O}=\mathrm{CH}_{4}+\mathrm{OH}^{*} \ldots \\
& \mathrm{C}+3 \mathrm{OH}^{\cdot}=\mathrm{CO}_{2}+\mathrm{H}_{3} \mathrm{O}^{\circ} \ldots \mathrm{OH}^{\cdot}+\mathrm{H}_{2} \mathrm{O}=\mathrm{H}_{3} \mathrm{O}^{\circ} \ldots \\
& \mathrm{C}+\mathrm{H}_{3} \mathrm{O}^{\cdot}=\mathrm{H}_{2} \mathrm{O}+\mathrm{CH}^{*} ; \mathrm{C}+\mathrm{H}^{\cdot}=\mathrm{CH}^{\cdot} \text {... et cetera. }
\end{aligned}
$$

The rate of release of methane depends on the temperature and pressure in the coalbed, coal rank and the size of coal particles.

By the study of temperature-pressure conditions in coalbed methane reservoirs of the Black Warrior basin Pashin and McIntyre [8] have recently shown that carbon sequestration and enhanced coalbed methane recovery show great promise in subcritical reservoirs.

Presence of water seems necessary for methane formation and methane sudden waste due to desorption processes only does not explain the phenomena quantita- tively. Mechanism of methane formation by a slightly endothermic reaction of carbon and water simultaneously with highly exothermic processes of the oxidation in the coal bed explains unpredictable evolution of the huge amounts of methane during exploitation of coal deposits.

\section{Conclusions}

Reaction of methane formation from carbon and water is a slightly endothermic process. Its energy could be compensated by exothermic reactions of partial or total oxidation of methane in the conditions of exploitation of coal deposits. The proposed mechanism of methane formation is confirmed by the results of the analysis of the hydrologic situation in the areas of coal-bed methane formation.

\section{References}

[1] I. L. Ettinger, "Huge reserves and unpredictable catastrophes," Moscow: Science, 1988.

[2] V. J. Hucka and D. M. Bodily, "Methane Formation in Utah Coals," SME 1993, Internet Available:

http://www.onemine.org/search/summary.cfm/MethaneFormation-In-Utah-Coals?d=838F8CCB0E722E7EFD1 8 B682C551854549145D57558153FB4E7FFCF7CA897C 2F5766.

[3] http://en.wikipedia.org/wiki/Methane_(data_page)\#Ther modynamic_properties

[4] U. Fehn, G. Snyder, W. C. Riese, et al., Coal bed methane formation and water movement: application of the I-129 and Cl-36 systems," 2001, Paper 23-0 GSA Annual Meeting.

[5] U. S. Department of the Interior, U. S. Geological Survey, USGS Fact Sheet FS-156-00, November 2000 http://pubs.usgs.gov/fs/fs-0156-00/

[6] S. L. Shvartsev, V. T. Khryukin, E. V. Domrocheva, et al, "Hydrogeology of the Erunakovo region of the Kuznetsk basin in the context of coal methane formation and mining," Russian Geology and Geophysics. Vol. 47, no.7, 2006, pp. 878-889.

[7] http://www.ags.gov.ab.ca/energy/cbm/coal_and_cbm_intr o2.html

[8] J. C. Pashin and M. R. McIntyre, "Temperature-pressure conditions in coalbed methane reservoirs of the Black Warrior basin: implications for carbon sequestration and enhanced coalbed methane recovery," Int. J. Coal Geol. Vol. 54, 2003, pp. 167-183. 